\title{
Genetic diversity of Sterculia quadrifida in Kupang, Indonesia based on RAPD (Random Amplified Polymorphic DNA) markers
}

\author{
USLAN $^{1, \bullet}$, MADE PHARMAWATI ${ }^{2}$ \\ ${ }^{1}$ Department of Biology Education, Faculty of Teacher Training and Education, Universitas Muhammadiyah Kupang. J1. KH. Ahmad Dahlan No. 17, \\ Kayu Putih, Oebobo, Kupang City 85111, East Nusa Tenggara, Indonesia. Tel.: +62-813-39430274, `email: uslanspd@ gmail.com \\ ${ }^{2}$ Department of Biology, Faculty of Mathematics and Natural Sciences, Universitas Udayana. Jl. Raya Kampus Unud No. 9, Jimbaran, Badung 80361, \\ Bali, Indonesia
}

Manuscript received: 18 June 2020. Revision accepted: 30 June 2020

\begin{abstract}
Uslan, Pharmawati M. 2020. Genetic diversity of Sterculia quadrifida in Kupang, Indonesia based on RAPD (Random Amplified Polymorphic DNA) markers. Biodiversitas 21: 3407-3414. This study aims to determine the genetic diversity of Sterculia quadrifida R.Br. in Kupang based on RAPD markers. Samples of S. quadrifida were collected from the yard and community forest in Kupang City (Sub-districts of Oebobo, Kelapa Lima, Maulafa, and Alak) and mixed forest in the Kupang District (Sub-districts of Kupang Barat, Nekamese, Taebenu, and Fatuleu). DNA was isolated by the CTAB method and amplified by six RAPD primers (OPD11, OPF-11, UBC-106, UBC-127, UBC-250, and OPB-04). The data were analyzed in the MVSP software using UPGMA method and Nei \& Li similarity coefficient. Total of 131 DNA bands ranging from 250-1400 bp was obtained. Populations of S. quadrifida in Kupang were divided into two main clusters and 12 sub-clusters with. The highest genetic diversity was found in Kelapa Lima of 0.1050 , while the lowest genetic diversity was found in S. quadrifida population in Fatuleu of 0.0305 . The population of $S$. quadrifida in Kupang has high genetic diversity and also clustered based on their geographical distribution
\end{abstract}

Keywords: Conservation, faloak, herbal, Kupang, RAPD, Sterculia quadrifida

\section{INTRODUCTION}

Faloak (Sterculia quadrifida R.Br.) is a medicinal plant that belongs to the family Sterculiaceae (Siswadi et al. 2013) and widely distributed in Nusa Tenggara Timur (NTT) Province. The distribution of $S$. quadrifida spread out throughout NTT island including Belu District, Timor Tengah Utara District, Timor Tengah Selatan District, Kupang District, and Kupang City) (Siswadi et al. 2013). S. quadrifida is a specific species of the dryland plants and able to survive in degraded land (BPS NTT, 2015).

Sterculia quadrifida has long been used as traditional medicine by the local community in Kupang. S. quadrifida bark contains flavonoids, phenolic, and has high antioxidant activity and proven to reduce pain, free radical's scavenger (Selly et al. 2015), to stimulate a nonspecific immune response (Winata et al. 2019), stimulate macrophage phagocytosis activity in vitro and as cancer chemopreventive (Hertiani et al. 2019). The use of herbal medicines that continues to expand rapidly in the past decades' especially $S$. quadrifida makes the existence of $S$. quadrifida to threaten (Saragih and Siswadi 2019). Furthermore, overharvesting of $S$. quadrifida or herbal drugs and natural health products will make $S$. quadrifida extinct the next years. Therefore, breeding efforts are needed to make for maintaining S. quadrifida existence.

Genetic diversity is one of three fundamental levels of biodiversity (besides species diversity and ecosystem diversity) that is directly important in conservation (Plenk et al. 2019). Genetic diversity indicates the origin of populations, their route of introduction, and explain their distribution and adaptation mechanisms at the local scale (Bzdega et al. 2016). Change in genetic diversity of species affects the genetic structure of the population. The changes are formally caused by evolutionary factors such as selection, mutation, migration, gene flow, and the marriage system (Ellegren and Galtier 2016). Genetic diversity is also closely related to population fitness. Many research proved that extinction is associated with low genetic diversity. Low genetic diversity also led to low juvenile survival, reduce population growth, and diminished adult lifespan (Plenk et al. 2019). Therefore, genetic variation of S. quadrifida is absolutely needed to be assessed in terms of their conservation.

Genetic diversity within species can be assessed by various techniques such as morphological, biochemical, and DNA (molecular markers) (Govindaraj et al. 2015). Assessing with morphological characters is strongly influenced by the environment, so its application in assessing genetic diversity should be evaluated (Sundari et al. 2017; Gusmiati et al. 2018). DNA molecular markers are the most widely used for assessing genetic diversity in recent decades (Govindaraj et al. 2015). The use of DNA molecular markers for assessing genetic diversity can provide more accurate information both for valid identification or basic knowledge of conservation.

Molecular markers were divided into three types based on their detection methods such as hybridization-based, PCR-based (Wahyudi et al. 2020), and DNA sequencebased (Nikmah et al. 2016). Restriction fragment length 
polymorphisms (RFLP) was the first hybridization-based markers developed for assessing genetic diversity in human, and later they were used in plant research (Hapsari et al. 2015). However, RFLPs are expensive and time consuming made them rarely used for the study of genetic diversity. Rapid amplified polymorphic DNAs (RAPDs) were the first PCR-based markers developed for determining genetic diversity (Govindaraj et al. 2015).

RAPD is PCR-based method and produced by PCR machines using genomic DNA and random primers. Quick and simple, inexpensive, and required a small amount of DNA make RAPD widely used in the study of genetic diversity. Many studies have proven the benefit of RAPD for both plant identification (Sundari et al. 2017; Probojati et al. 2019) or mutant detection (Wahyudi et al. 2020), even in assessing genetic diversity (Ozbek and Kara 2013). Therefore, the aim of this study is to evaluate the genetic diversity of $S$. quadrifida in Kupang, Indonesia.

\section{MATERIALS AND METHODS}

\section{Sample collection}

Twenty-two individuals of $S$. quadrifida were used in this study. The samples were collected from eight sites in Kupang City and Kupang District, East Nusa Tenggara, Indonesia. Fresh young leaves of every individual sample were collected and used as DNA extraction. Samples of $S$. quadrifida were collected from the yard, and community forest in Kupang with coordinates and altitudes as shown in Table 1.

Table 1. Sampling locations and coordinates of S. quadrifida in the yard and community forest of Kupang, Indonesia

\begin{tabular}{|c|c|c|c|}
\hline $\begin{array}{c}\text { Sub- } \\
\text { district }\end{array}$ & $\begin{array}{c}\begin{array}{c}\text { Total } \\
\text { no. of } \\
\text { samples }\end{array} \\
\end{array}$ & Coordinates & $\begin{array}{c}\text { Altitude } \\
\text { (m } \\
\text { a.s.l.) }\end{array}$ \\
\hline \multirow[t]{3}{*}{ Oebobo } & \multirow[t]{3}{*}{3} & $123^{\circ} 37.088^{\prime} \mathrm{E}, 10^{\circ} 09.765^{\prime} \mathrm{S}$ & 97 \\
\hline & & $123^{\circ} 37.193^{\prime} \mathrm{E}, 10^{\circ} 09.755^{\prime} \mathrm{S}$ & 71 \\
\hline & & $123^{\circ} 37.254^{\prime} \mathrm{E}, 10^{\circ} 09.795^{\prime} \mathrm{S}$ & 85 \\
\hline Kelapa & \multirow[t]{4}{*}{4} & $123^{\circ} 34.036^{\prime} \mathrm{E}, 10^{\circ} 09.082^{\prime} \mathrm{S}$ & 55 \\
\hline \multirow[t]{3}{*}{ Lima } & & $123^{\circ} 39.402^{\prime} \mathrm{E}, 10^{\circ} 09.153^{\prime} \mathrm{S}$ & 54 \\
\hline & & $123^{\circ} 36.585^{\prime} \mathrm{E}, 10^{\circ} 09.198^{\prime} \mathrm{S}$ & 43 \\
\hline & & $123^{\circ} 37.722^{\prime} \mathrm{E}, 10^{\circ} 09.072^{\prime} \mathrm{S}$ & 63 \\
\hline \multirow[t]{3}{*}{ Maulafa } & \multirow[t]{3}{*}{3} & $123^{\circ} 36.525^{\prime} \mathrm{E}, 10^{\circ} 14.103^{\prime} \mathrm{S}$ & 272 \\
\hline & & $123^{\circ} 36.609^{\prime} \mathrm{E}, 10^{\circ} 15.258^{\prime} \mathrm{S}$ & 290 \\
\hline & & $123^{\circ} 36.941^{\prime} \mathrm{E}, 10^{\circ} 15.576^{\prime} \mathrm{S}$ & 195 \\
\hline \multirow[t]{3}{*}{ Alak } & \multirow[t]{3}{*}{3} & $123^{\circ} 34.064^{\prime} \mathrm{E}, 10^{\circ} 10.260^{\prime} \mathrm{S}$ & 67 \\
\hline & & $123^{\circ} 33.028^{\prime} \mathrm{E}, 10^{\circ} 10.359^{\prime} \mathrm{S}$ & 7 \\
\hline & & $123^{\circ} 32.602^{\prime} \mathrm{E}, 10^{\circ} 10.330^{\prime} \mathrm{S}$ & 10 \\
\hline Kupang & \multirow[t]{3}{*}{3} & $123^{\circ} 28.891^{\prime} \mathrm{E}, 10^{\circ} 18.974^{\prime} \mathrm{S}$ & 2 \\
\hline \multirow[t]{2}{*}{ Barat } & & $123^{\circ} 28.820^{\prime} \mathrm{E}, 10^{\circ} 19.024^{\prime} \mathrm{S}$ & 1 \\
\hline & & $123^{\circ} 28.586^{\prime} \mathrm{E}, 10^{\circ} 19.083^{\prime} \mathrm{S}$ & 1 \\
\hline \multirow[t]{2}{*}{ Nekamese } & \multirow[t]{2}{*}{2} & $123^{\circ} 37.217^{\prime} \mathrm{E}, 10^{\circ} 12.852^{\prime} \mathrm{S}$ & 455 \\
\hline & & $123^{\circ} 37.750^{\prime} \mathrm{E}, 10^{\circ} 13.262^{\prime} \mathrm{S}$ & 484 \\
\hline \multirow[t]{2}{*}{ Taebenu } & \multirow[t]{2}{*}{2} & $123^{\circ} 42.606^{\prime} \mathrm{E}, 10^{\circ} 13.298^{\prime} \mathrm{S}$ & 121 \\
\hline & & $123^{\circ} 42.562^{\prime} \mathrm{E}, 10^{\circ} 13.050^{\prime} \mathrm{S}$ & 240 \\
\hline \multirow[t]{2}{*}{ Fatuleu } & \multirow[t]{2}{*}{2} & $123^{\circ} 55.287^{\prime} \mathrm{E}, 10^{\circ} 02.530^{\prime} \mathrm{S}$ & 104 \\
\hline & & $123^{\circ} 55.163^{\prime} \mathrm{E}, 10^{\circ} 02.439^{\prime} \mathrm{S}$ & 199 \\
\hline
\end{tabular}

Note: Sub-districts of Oebobo, Kelapa Lima, Malafa and Alak located in Kupang City, whereas Sub-districts of Kupang Barat, Nekamese, Taebenu, and Fatuleu located in Kupang District

\section{DNA isolation and quantification}

DNA was extracted from young leaves using the modified CTAB method according to Doyle dan Doyle (1990). A total $0.1 \mathrm{~g}$ of leaf samples were crushed with mortar and pestle, then added $1 \mu \mathrm{L}$ extraction buffer [2\% CTAB, $1.4 \mathrm{M} \mathrm{NaCl}, 0.2 \% \quad \beta$-mercaptoethanol, $50 \mathrm{mM}$ $\mathrm{Na}_{2}$ EDTA (pH 8.0), $100 \mathrm{mM}$ Tris-HCL (pH 8.0)]. The sample was incubated at $65{ }^{\circ} \mathrm{C}$ in a water bath for $60 \mathrm{~min}$. and inverted every $10 \mathrm{~min}$. Samples were added $700 \mu \mathrm{L}$ chloroform: isoamyl alcohol (24: 1) and vortexed, then centrifuged at 12,000 rpm for 5 minutes. The supernatant was transferred to a new tube, and cold ethanol was added according to the amount of supernatant collected from the previous tube. The tube was mixed gently and incubated for 1 hour in a freezer at $-20{ }^{\circ} \mathrm{C}$. Furthermore, the tubes were centrifuged at a speed of $12,000 \mathrm{rpm}$ for $3 \mathrm{~min}$., the supernatant was discarded carefully, and pellets washed with $70 \%$ alcohol as much as $400 \mu \mathrm{L}$, then centrifuged for $3 \mathrm{~min}$. at a speed of $12,000 \mathrm{rpm}$. The supernatant was removed, and the pellet was dried over the tissue until the alcohol was completely gone. After drying, the pellet in the tube was added with $100 \mu \mathrm{L}$ of sterile $\mathrm{H}_{2} \mathrm{O}$ to dissolve the DNA pellet. Furthermore, it was stored as a stock at $-20^{\circ} \mathrm{C}$.

The DNA concentration was determined by comparing it with lambda DNA (50 $\mathrm{ng} / \mu \mathrm{L})$. Isolated DNA was electrophoresed with $1.8 \%$ agarose gel in $1 \mathrm{x}$ TAE buffer [40 mM Tris-acetate (pH 7.9) and $2 \mathrm{mM} \mathrm{Na} 2$ EDTA]. A total of $3 \mu \mathrm{L}$ of the sample was mixed with loading dye on parafilm paper. Each sample mixture was put into a gel well. Lambda DNA $100 \mathrm{ng}\left(\lambda_{1}\right), 200 \mathrm{ng}\left(\lambda_{2}\right)$, and $300 \mathrm{ng}$ $\left(\lambda_{3}\right)$ were put into the gel well to estimate DNA concentration. Electrophoresis was performed in a 100-volt voltage for $30 \mathrm{~min}$. The gel was soaked in ethidium bromide (EtBr) for $30 \mathrm{~min}$., then observed in GelDoc UV Transilluminator (Sambrook and Russell 2001).

\section{RAPD (Random Amplified Polymorphic DNA)}

RAPD analysis used six primers (Table 2) for PCR amplification. The PCR was carried out at a total volume of $25 \mu \mathrm{L}$ containing a mixture of $0.2 \mathrm{mM}$ dNTPs, three mM $\mathrm{MgCl}_{2}, 1 \mathrm{U}$ Taq DNA Polymerase, $1 \mathrm{x}$ buffer polymerase, $1.9 \mu \mathrm{M}$ primers, $50 \mathrm{ng}$ DNA and sterile water up to a volume of $25 \mu \mathrm{L}$. Amplification was carried out in a thermocycler with cycle program conditions as initial denaturation at a temperature of $94^{\circ} \mathrm{C}$ for $2 \mathrm{~min}$. (one time), followed by denaturation at $94^{\circ} \mathrm{C}$ for $2 \mathrm{~min}$., annealing at $36^{\circ} \mathrm{C}$ for $2 \mathrm{~min}$., elongation at $72^{\circ} \mathrm{C}$ for $2 \mathrm{~min}$. for 45 cycles. The final condition was the elongation at $72{ }^{\circ} \mathrm{C}$ for 10 min. (one time). The PCR results were electrophoresed on $1.8 \%$ agarose gel with a 100-volt voltage for 40 minutes. A total of $10 \mu \mathrm{L}$ of PCR products were mixed with loading dye on parafilm paper. The DNA ladder 100 bp was inserted into the gel well as much as $5 \mu \mathrm{L}$ to determine the size of the DNA band. Staining was done by soaking the gel in $\mathrm{EtBr}$ for $30 \mathrm{~min}$. PCR product observations were carried out with GelDoc UV Transilluminator (Sambrook and Russell 2001). 
Table 2. RAPD primers used in this study

\begin{tabular}{ll}
\hline Nama primer & Urutan basa \\
\hline OPD-11 & 5'-AGCGCCATTG-3' \\
OPF-11 & 5'-TTGGTACCCC-3' \\
UBC-106 & 5'-CGTCTGCCCG-3' \\
UBC-127 & 5'-ATCTGGCAGC-3' \\
UBC-250 & 5'-CGACAGTCCC-3' \\
OPB-04 & 5'-GGACTGGAGT3' \\
\hline
\end{tabular}

\section{Data analysis}

The size of the DNA bands was determined by plotting on semilog paper. The migration distance from the gel well to the middle was measured with ladder bands. The distance from the well to the middle of the ladder bands was plotted on the $\mathrm{X}$-axis, while the size of the DNA on the ladder was plotted on the $\mathrm{Y}$-axis. The points on the semilog paper were connected to make a standard curve. Migration distance measured from the PCR product obtained, then plotted on a standard curve to determine its size.

DNA bands of known size were then scored. The DNA band was given a score one (1) if present and a score zero (0) if absent. The obtained matrix data then was subjected to cluster analysis by using the unweighted pair group method with arithmetic mean (UPGMA) method based on the Nei \& Li similarity coefficient through the MVSP (Multi-Variate Statistical Package) 3.2 software program (Damayanto 2012). The level of primer informativeness was determined by calculating the Polymorphic Information Content (PIC). PIC is calculated by equation 1:

$$
\mathrm{PIC}_{j}=1-\sum_{i=1}^{n} P_{i}^{2}
$$

Where; $i$ is an allele of the $j$ marker, $n$ is the number of the $j$ marker's alleles, $P$ is allele frequency. The genetic variation parameters sought in this study are by using the following formula (Finkeldey 2001):

The number of effective alleles $(\mathrm{Na})$ was calculated by using equation 2 :

$$
N a=\frac{1}{\sum p i^{2}}
$$

The number of alleles observed $(\mathrm{Ne})$ was calculated by using equation 3 :

$$
N e=\frac{\sum \text { Alel }}{\sum \text { Lokus }}
$$

Average heterozygosity/genetic diversity (He) was calculated by using equation 4 :

$$
H e=1-\sum_{i=1}^{l} P_{i}^{2}
$$

Where; $P i$ is the frequency of the $i$ allele among the total number of alleles $l$.

\section{RESULTS AND DISCUSSION}

\section{Polymorphism analysis of Sterculia quadrifida}

DNA Amplification of $S$. quadrifida using six primers (OPD-11, OPF-11, UBC-106, UBC-127, UBC-250, and OPB-04) produced 131 DNA bands ranging from 2501400bp (Table 3). The highest total number band (TNB) was obtained by UBC-106, whereas the lowest was UBC127 (Figure 1). All primers showed the same PIC values since all primers produce $100 \%$ polymorphic bands (Table $3)$.

DNA bands are the result of pairing nucleotides from primers with plant genome nucleotides (Lorenz 2012). In this study, the bands produced do not always have the same intensity. Electrophoresis results showed clear and faint bands. According to Wahyudi et al. (2020), the amount and intensity of the DNA bands produced are highly dependent on the ability of the primer to recognizing the complementary DNA sequence in the DNA template. In addition, there are various DNA bands because the number of amplified templates represent an unequal band. There are enough repetitive DNA bands that appear as very clear DNA bands, and there are only a few templates and not enough to be visible as clear bands so that look thin and faint (Lorenz 2012).

DNA amplification also depends on the compatibility of the primer with the DNA sequence of the S. quadrifida. Non-compliant primers will not produce amplification products because there are no complementary sites on the DNA of $S$. quadrifida with the primer sequence. In this study, DNA amplification produced DNA bands with sizes ranging from 250-1400 bp. The different DNA band size is due to differences in the length of DNA sites in plants which can be extended by primers. The wider the distance between the primer site and the others in the DNA template will produce a long new DNA with high molecular weight (Wahyudi et al. 2020). RAPD uses synthetic oligonucleotides (around $10 \mathrm{bp}$ ) as primers and requires a small amount of DNA. Furthermore, RAPD primers are usually able to amplify DNA with sizes of 100-3000 bp depending on genomic and primer (Wahyudi et al. 2020; Rahiman et al. 2015).

Table 3. Polymorphism analysis results of six RAPD primers amplification of Sterculia quadrifida from Kupang, Indonesia

\begin{tabular}{lccccc}
\hline Primer & $\begin{array}{c}\text { DNA } \\
\text { amplification } \\
\text { size (bp) }\end{array}$ & TNB & NPB & $\begin{array}{c}\text { PB } \\
(\boldsymbol{\%})\end{array}$ & PIC \\
\hline OPD-11 & $250-1100$ & 25 & 25 & 100 & 0.95 \\
OPF-11 & $300-980$ & 19 & 19 & 100 & 0.95 \\
UBC-106 & $310-1200$ & 27 & 27 & 100 & 0.95 \\
UBC-127 & $430-1400$ & 11 & 11 & 100 & 0.95 \\
UBC-250 & $290-1300$ & 25 & 25 & 100 & 0.95 \\
OPB-04 & $290-1180$ & 24 & 24 & 100 & 0.95 \\
\hline
\end{tabular}

Note. TNB: total number of bands; NPB: number of polymorphic bands; PB (\%): polymorphic band percentage; PIC: polymorphism information content 


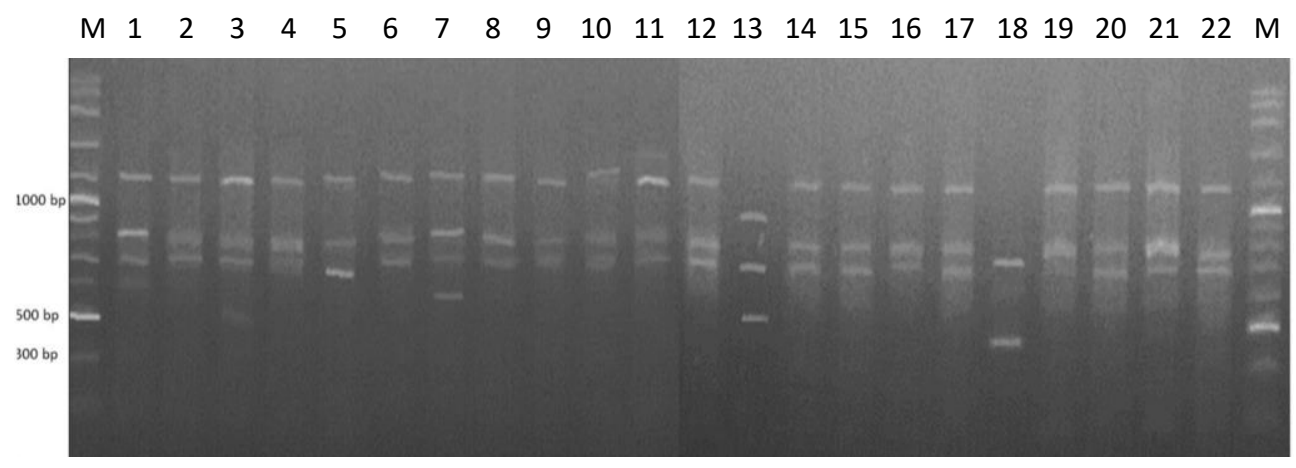

Figure 1. RAPD-PCR profile from the UBC-127 primer (Note: the numbers sequentially, Oebobo [1-3], Kelapa Lima [4-7], Maulafa [810], Alak [11-13], Kupang [14-16], Nekamese [17-18], Taebenu [19-20], Fatuleu [21-22], DNA Ladder VC 100bp Plus [M])

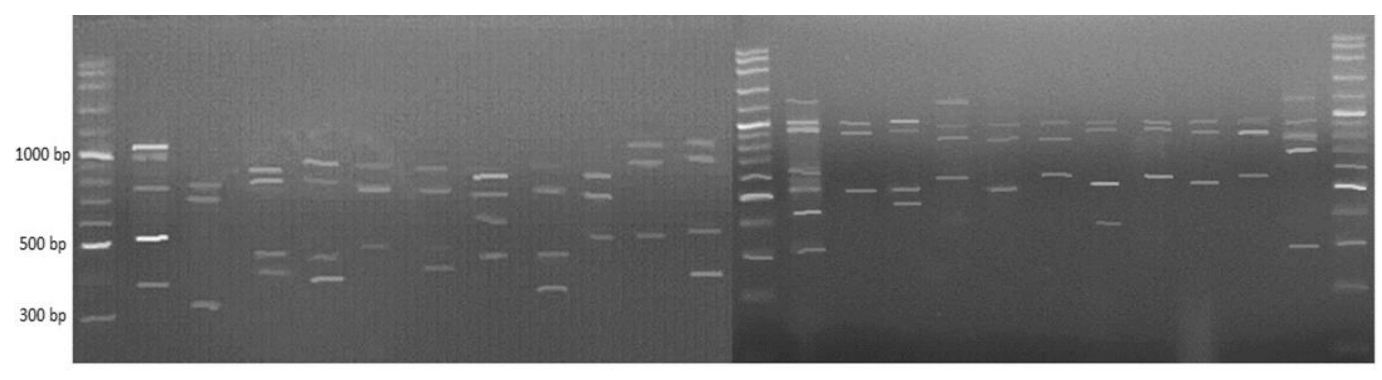

Figure 2. RAPD-PCR profile from the UBC-106 primer (Note: the numbers sequentially, Oebobo [1-3], Kelapa Lima [4-7], Maulafa [810], Alak [11-13], Kupang [14-16], Nekamese [17-18], Taebenu [19-20], Fatuleu [21-22], DNA Ladder VC 100bp Plus [M])

Polymorphism is characterized by the presence and absence of the band in the sample and the difference in the size of the band produced by each sample. The polymorphism of $S$. quadrifida in Kupang with eight populations is $100 \%$, based on polymorphic band percentage (Table 3). UBC-106 is one of six primers that produce the highest polymorphic DNA bands (Figure 2). It produces 27 DNA bands, and all of them are polymorphic (Table 3). DNA polymorphisms are the different DNA sequences among individuals, groups, or populations. Polymorphism occurs in the same population of two or more alleles at one locus, each with a significant enough frequency, where the minimum frequency is usually $1 \%$ (Sukhumsirichart 2018).

The level of polymorphism information content (PIC) is 0.95, which means that the primer can detect polymorphism in a population of $95 \%$ in all S. quadrifida samples (Table 3). The PIC is the probability that the marker genotype of heterozygous offspring affected by the parent and often used to measure genetic marker information for linkage studies. PIC refers to the value of a marker to detect polymorphism in a population. Furthermore, PIC depends on the number of alleles and their frequency distribution. The higher the PIC value of a primer, the better the primer to be used as a molecular marker (Graebner et al. 2016)

\section{Genetic distance, clustering, and genetic variation of Sterculia quadrifida}

DNA band profiles from the amplification showed genetic diversity in S. quadrifida (Table 4). Sub-districts of Taebenu 2 and Kelapa Lima 3 have the highest genetic distance or lowest similarity value (Table 5). These two sub-districts are geographically apart. The population of Taebenu 2 is in the area of Kupang District and the population of Kelapa Lima 3 is in Kupang City. The lowest genetic distance was found in samples of $S$. quadrifida in Alak 1 and Maulafa 3 (Table 5).

Table 4. Result of genetic variation estimations of Sterculia quadrifida in the Kupang, Indonesia

\begin{tabular}{lccccc}
\hline \multicolumn{1}{c}{ Population } & $\begin{array}{c}\text { Total } \\
\text { sample }\end{array}$ & Na & Ne & He & PLP \\
\hline Oebobo & 3 & 1.1985 & 0.8189 & 0.0882 & 19.85 \\
Kelapa Lima & 4 & 1.2672 & 0.7561 & 0.1050 & 26.72 \\
Maulafa & 3 & 1.1679 & 0.8460 & 0.0746 & 16.79 \\
Alak & 3 & 1.2214 & 0.8010 & 0.0984 & 22.14 \\
Kupang Barat & 3 & 1.1450 & 0.8681 & 0.0645 & 14.50 \\
Taebenu & 2 & 1.1221 & 0.8915 & 0.0611 & 12.21 \\
Nekamese & 2 & 1.0992 & 0,9095 & 0.0496 & 9.92 \\
Fatuleu & 2 & 1.0611 & 0.9439 & 0.0305 & 6.11 \\
\hline
\end{tabular}

Note: Na: number of alleles; Ne: number of effective alleles; He: expected heterozygosity; PLP: percentage locus polymorphic 
The genetic variation of $S$. quadrifida in this study may be caused by animals (types of pollinators and herbivores) and geographical conditions of the subject area. Geographically, S. quadrifida capable of growing in various types of the slope, from flat to steep slopes, and are usually found near the river that allows the seeds to carried by water and then spread and grow along with the river flow. Besides, as in general forest plants, these plants do cross-breeding which is assisted by the wind to provide a higher likelihood for random pollination that allows the process of gene transfer or migration through pollen displacement can cover a reasonably widespread area (Siswadi et al. 2013). Woody plants such as S. quadrifida have considerable variability for interbreeding. Besides, species that are more widely distributed with large and close together populations have high productivity and large genetic variability (Hahn et al. 2017).

The parameters used to indicate genetic diversity in the population are percentage locus polymorphic (PLP), the observed number of alleles $(\mathrm{Na})$, the effective number of the alleles $(\mathrm{Ne})$ and expected heterozygosity ( $\mathrm{He})$ (Yulita and Rahmat 2019). The average observed number of an allele in S. quadrifida populations in Kupang is 1.1603 , and the average effective number of the alleles is 0.8544 . The average value of expected heterozygosity in the total population of $S$. quadrifida that grow in Kupang is 0.0715 . Furthermore, based on the results of genetic variation analysis (Table 4), it shows that $S$. quadrifida has the high genetic diversity in Kelapa Lima (0.1050), Alak (0.0984), and Oebobo (0.0882). Whereas in the population in the Kupang District, the lowest expected heterozygosity (He) value was found in Fatuleu (0.0305). From these data, it can be concluded that genetic diversity within the population of Kelapa Lima (Kupang City) is greater than other populations in the City and District of Kupang.

High genetic diversity in $S$. quadrifida populations can arise due to natural mutations. The value of genetic diversity in populations of Fatuleu (Kupang District) may be associated with increased habitat fragmentation and population isolation, which contributes to low genetic variation (Plenk et al. 2019). Besides, it could also be influenced by geographical and reproductive isolation, so pollination is not possible between individuals in a population with other populations (Bhandari et al. 2017). Differences in genetic diversity of the eight $S$. quadrifida plant populations (Table 4), shows that $S$. quadrifida plants from Fatuleu had the lowest genetic diversity in the population (0.0305) compared to the population in Kelapa Lima with the highest genetic diversity in the population (0.1050). The large differences in genetic diversity in populations can be caused by several factors such as isolation by distance, geography, ecology, and reproduction. If this happens, a new type of plant will emerge that is able to adapt to its environment (Yulita and Rahmat 2019).

Genetic diversity is also influenced by the markers used and also the number of primers. In this study, RAPD markers are quite sensitive methods in detecting the genetic structure of populations (Rahiman et al. 2015). The results of this study can be a reference to support plant breeding activities. Besides, high genetic diversity is also beneficial in the implementation of conservation of forest plants, as well as for the preservation of genetic diversity of $S$. quadrifida. In addition, species with high genetic diversity also capable of occupying new areas and likely to have an excellent opportunity to escape natural selection and survive extinction (Bhandari et al. 2017; Hahn et al. 2017).

Based on minimal similarity $>0.5, S$. quadrifida in Kupang was divided into two main clusters and 12 subclusters. The first cluster comprises $S$. quadrifida population in Kupang City and Kupang District, formed six sub-clusters. The first sub-cluster consists of Nekamese 1, Taebenu 1, and Taebenu 2 (Kupang District), the second sub-cluster consists of population Fatuleu 1 and Fatuleu 2 (Kupang District), the third sub-cluster only consists of one population namely Nekamese 2 (Kupang District), the fourth sub-cluster consists of the population of Kupang Barat 2 and Kupang Barat 3 (Kupang District), the fifth sub-cluster consists of only one population namely Kupang Barat 1 (Kupang District) and the sixth sub-cluster consists of two populations of Alak 2 and Alak 3 (Kupang City) (Figure 3). While the second cluster was composed by all the population in Kupang City which formed six subclusters, namely the population sub-cluster of Kelapa Lima 1, the population sub-cluster of Oebobo 2 and Oebobo 3, the population sub-cluster of Maulafa 1, the population sub-cluster of Kelapa Lima 2, Kelapa Lima, 3 and Kelapa Lima 4, the population sub-cluster of Alak 1, Maulafa 2 and Maulafa 3, and the last population sub-cluster of Oebobo 1.

Populations of S. quadrifida in Kupang were clustered according to their geographical position. The closer the geographical distance between population of $S$. quadrifida in Kupang was the closest genetic distance between these populations. Adjacent populations generally form one subcluster, for example, Fatuleu 1 and 2 populations (Kupang District), and the populations of Kelapa Lima 2, 3, and 4 (Kupang City) are in one sub-cluster (Figure 3). The examples show that the population originating from the same area will have a close kinship. However, there are some populations that show different trends. Alak 1 population has closer kinship with a population of Maulafa 2 and Maulafa 3. Although all three population areas are located in Kupang City, the geographical location of each area is different (Table 1).

Not all populations from one region are in one cluster. This means that clustering based on genetic distance does not always show a real relationship with the geographical distribution of $S$. quadrifida populations from the same habitat. It occurs due to the environmental factors or the existence of genotypic interactions with the environment (Bhandari et al. 2017). In addition, S. quadrifida used in the study had varied ages which led to genetic diversity in that population (Carvalho et al. 2019). However, the tendency of such clustering is also shown in the results of research on plants that do cross-breeding (Louwaars 2018). 
Tabel 5. Similarity analysis of UPGMA method clustering with MVSP program of 22 Sterculia quadrifida plant samples based on Nei \& Li's coefficient

\begin{tabular}{|c|c|c|c|c|c|c|c|c|c|c|c|c|c|c|c|c|c|c|c|c|c|c|}
\hline No & 1 & 2 & 3 & 4 & 5 & 6 & 7 & 8 & 9 & 10 & 11 & 12 & 13 & 14 & 15 & 16 & 17 & 18 & 19 & 20 & 21 & 22 \\
\hline 1 & 1.00 & & & & & & & & & & & & & & & & & & & & & \\
\hline 2 & 0.33 & 1.00 & & & & & & & & & & & & & & & & & & & & \\
\hline 3 & 0.39 & 0.60 & 1.00 & & & & & & & & & & & & & & & & & & & \\
\hline 4 & 0.31 & 0.47 & 0.47 & 1.00 & & & & & & & & & & & & & & & & & & \\
\hline 5 & 0.33 & 0.28 & 0.34 & 0.36 & 1.00 & & & & & & & & & & & & & & & & & \\
\hline 6 & 0.18 & 0.26 & 0.28 & 0.25 & 0.59 & 1.00 & & & & & & & & & & & & & & & & \\
\hline 7 & 0.26 & 0.41 & 0.37 & 0.34 & 0.53 & 0.58 & 1.00 & & & & & & & & & & & & & & & \\
\hline 8 & 0.26 & 0.20 & 0.27 & 0.38 & 0.43 & 0.47 & 0.37 & 1.00 & & & & & & & & & & & & & & \\
\hline 9 & 0.27 & 0.16 & 0.19 & 0.20 & 0.37 & 0.25 & 0.30 & 0.34 & 1.00 & & & & & & & & & & & & & \\
\hline 10 & 0.41 & 0.21 & 0.24 & 0.30 & 0.41 & 0.25 & 0.25 & 0.48 & 0.63 & 1.00 & & & & & & & & & & & & \\
\hline 11 & 0.44 & 0.25 & 0.27 & 0.29 & 0.57 & 0.43 & 0.42 & 0.37 & 0.55 & 0.65 & 1.00 & & & & & & & & & & & \\
\hline 12 & 0.12 & 0.04 & 0.13 & 0.09 & 0.12 & 0.04 & 0.13 & 0.13 & 0.14 & 0.09 & 0.13 & 1.00 & & & & & & & & & & \\
\hline 13 & 0.09 & 0.11 & 0.10 & 0.15 & 0.23 & 0.15 & 0.20 & 0.15 & 0.16 & 0.10 & 0.15 & 0.48 & 1.00 & & & & & & & & & \\
\hline 14 & 0.23 & 0.16 & 0.14 & 0.20 & 0.14 & 0.10 & 0.15 & 0.24 & 0.10 & 0.21 & 0.15 & 0.38 & 0.48 & 1.00 & & & & & & & & \\
\hline 15 & 0.18 & 0.10 & 0.14 & 0.10 & 0.22 & 0.20 & 0.19 & 0.23 & 0.25 & 0.2 & 0.24 & 0.32 & 0.21 & 0.51 & 1.00 & & & & & & & \\
\hline 16 & 0.18 & 0.10 & 0.14 & 0.20 & 0.18 & 0.15 & 0.20 & 0.14 & 0.26 & 0.21 & 0.25 & 0.33 & 0.32 & 0.42 & 0.56 & 1.00 & & & & & & \\
\hline 17 & 0.23 & 0.16 & 0.15 & 0.21 & 0.23 & 0.15 & 0.20 & 0.20 & 0.16 & 0.21 & 0.20 & 0.19 & 0.27 & 0.21 & 0.36 & 0.43 & 1.00 & & & & & \\
\hline 18 & 0.09 & 0.11 & 0.05 & 0.16 & 0.09 & 0.01 & 0.05 & 0.05 & 0.05 & 0.05 & 0.10 & 0.20 & 0.28 & 0.16 & 0.16 & 0.33 & 0.57 & 1.00 & & & & \\
\hline 19 & 0.09 & 0.17 & 0.10 & 0.16 & 0.19 & 0.10 & 0.10 & 0.20 & 0.16 & 0.16 & 0.15 & 0.25 & 0.40 & 0.33 & 0.37 & 0.44 & 0.62 & 0.64 & 1.00 & & & \\
\hline 20 & 0.09 & 0.15 & 0.09 & 0.15 & 0.22 & 0.15 & 0.19 & 0.09 & 0.20 & 0.10 & 0.24 & 0.27 & 0.31 & 0.41 & 0.40 & 0.51 & 0.31 & 0.32 & 0.43 & 1.00 & & \\
\hline 21 & 0.09 & 0.11 & 0.10 & 0.16 & 0.14 & 0.21 & 0.21 & 0.25 & 0.22 & 0.22 & 0.15 & 0.20 & 0.28 & 0.38 & 0.48 & 0.50 & 0.28 & 0.17 & 0.41 & 0.54 & 1.00 & \\
\hline 22 & 0.17 & 0.10 & 0.09 & 0.23 & 0.13 & 0.19 & 0.18 & 0.22 & 0.14 & 0.24 & 0.14 & 0.17 & 0.25 & 0.29 & 0.33 & 0.39 & 0.35 & 0.20 & 0.30 & 0.33 & 0.61 & 1.00 \\
\hline
\end{tabular}

Note: Oebobo [1-3], Kelapa Lima [4-7], Maulafa [8-10], Alak [11-13], Kupang [14-16], Nekamese [17-18], Taebenu [19-20], Fatuleu [21-22]. Shadings indicate the highest and the lowest of similarity coefficient. 


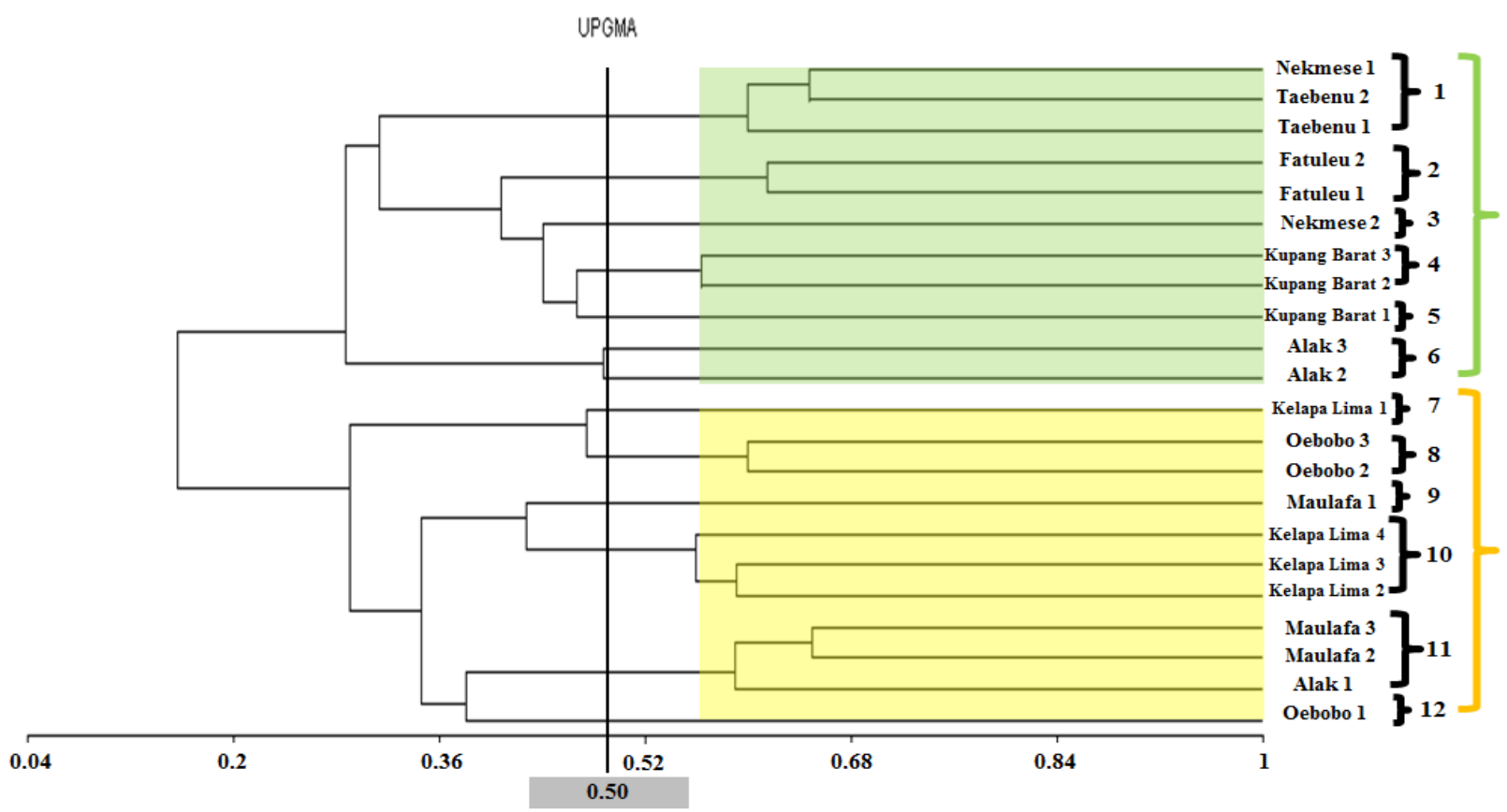

Figure 3. Dendrogram of 22 samples of Sterculia quadrifida based on the coefficient of similarity of Nei \& Li with the UPGMA method in the MVSP program (Note: numbers below the dendrogram shows Nei \& Li similarity coefficient value, while the numbers to the right of the dendrogram indicate clustering)

It is concluded that the population of $S$. quadrifida in Kupang has high genetic diversity. Populations of $S$. quadrifida were also clustered based on their geographical distribution. The results of this study will be useful to support $S$. quadrifida conservation.

\section{ACKNOWLEDGEMENTS}

The author greatly appreciates Dr. I Ketut Ginantra, for his supervising and Head of the Biotechnology Laboratory of the Agroecotechnology Department, Faculty of Agriculture, Udayana University, Bali, Indonesia for permission to use the laboratory.

\section{REFERENCE}

Bhandari HR, Bhanu AN, Srivastava K, Singh MN, Shreya, Hemantaranjan A. 2017. Assessment of genetic diversity in crop plants-an overview. Adv Plants Agric Res 7 (3): 25. DOI: 10.15406/apar.2017.07.00255

BPS NTT [Badan Pusat Satistik Provinsi Nusa Tenggara Timur]. 2015. Nusa Tenggara Timur Dalam Angka 2016. BPS NTT, Kupang. [Indonesian]

Bzdega K, Agnieszka J, Tomasz K, Agata L, Małgorzata G, Elwira S, Barbara TG. 2016. A survey of genetic variation and genome evolution within the invasive fallopia complex. PLoS ONE 11 (8): e0161854. DOI: 10.1371/journal.pone.0161854.

Carvalho YGS, Luciana CV, Ueric JBS, Layara AB. 2019. Recent trends in research on the genetic diversity of plants: Implications for conservation. Diversity 11 (62): 1-21.

Doyle JJ, Doyle JL. 1990. Isolation of plant DNA from fresh tissue. Focus 12: $13-15$
Ellegren H, Galtier N. 2016. Determinants of genetic diversity. Nature Rev Genet 17 (7): 422-33.

Elly JB, Abdurrouf, Juswono UP. 2015. Effect of Sterculia quadrifide R.Br. extract against free radical in liver organ Oreochromis niloticus due to heavy metal pollution. Natural B J Health Environ Sci 3 (2): 175-181. DOI: 10.21776/ub.natural-b.2015.003.02.11.

Finkeldey R. 2001. An Introduction To Tropical Forest Genetics. Institute of Forest Genetics and Forest Tree Breeding, Gottingen.

Govindaraj M, Vetriventhan M, Srinivasan M. 2015. Importance of Genetic Diversity assessment in crop plants and its recent advances: an overview of its analytical perspectives. Gen Res Intl 431487: 1-14. DOI: $10.1155 / 2015 / 431487$

Graebner RC, Hayes PM, Hagerty CH, Cuesta-Marcos A. 2016. A comparison of polymorphism information content and mean of transformed kinships as criteria for selecting informative subsets of barley (Hordeum vulgare L. s. 1.) from the USDA Barley Core Collection. Genet Resour Crop Evol (2016) 63: 477-482. DOI 10.1007/s10722-015-0265-Z

Gusmiati LH, Hapsari L, Wahyudi D. 2018. Keragaman dan pengelompokan morfologi 10 pisang olahan (Musa cv. Grup ABB) koleksi Kebun Raya Purwodadi LIPI. Floribunda 5 (8): 299-313. [Indonesian]

Hahn CZ, Michalski SG, Fischer M, Durka W. 2017. Genetic diversity and differentiation follow secondary succession in a multi-species study on woody plants from subtropical China. J Plant Ecol 10 (1): 213-221.

Hapsari L, Wahyudi D, Azrianingsih R, Arumingtyas EL. 2015. Genome identification of bananas (Musa L.) from East Java Indonesia assessed with PCR-RFLP of the internal transcribed spacers nuclear ribosomal DNA. Intl J Biosci 7 (3): 42-52.

Hertiani T, Purwantiningsih, Aji W, Widyandani S, Rima M, Erna PS, Retno M, Siswadi. 2019. In vitro immunomodulatory and cytotoxic potentials of faloak (Sterculia quadrifida R.Br.) bark. Online J Biol Sci 19 (4): 222-231.

Lorenz TC. 2012. Polymerase Chain Reaction: Basic protocol plus troubleshooting and optimization strategies. J Visual Exp 63: 1-15. DOI: $10.3791 / 3998$. 
Louwaars NP. 2018. Plant breeding and diversity: A troubled relationship?. Euphytica 2018: 214:114. DOI: 10.1007/s10681-0182192-5

Nikmah IA, Azrianingsih R, Wahyudi D. 2016. Genetic diversity of porang populations (Amorphophallus muelleri Blume) in Central Java and West Java based on LEAFY second intron marker. J Trop Life Sci 6 (1): 23-27.

Ozbek O, Kara A. 2013. Genetic variation in natural populations of Capparis from Turkey, as revealed by RAPD analysis. Plant Syst Evol 299: 1911-1933.

Plenk K, Bardy K, Höhn M, Kropf M. 2019. Long-term survival and successful conservation? Low genetic diversity but no evidence for reduced reproductive success at the north-westernmost range edge of Poa badensis (Poaceae) in Central Europe. Biodiv Conserv 28: 1245 1265. DOI: $10.1007 / \mathrm{s} 10531-019-01722-\mathrm{x}$

Probojati RT, Wahyudi D, HapsariL. 2019. Clustering analysis and genome inference of pisang raja local cultivars (Musa spp.) from Java Island by Random Amplified Polymorphic DNA (RAPD) marker. J Trop Biodiv Biotechnol 4 (02): 42-53.

Rahiman FOM, Balasubramanian T, Pawan K, Shejina M. 2015. National Conference on Advances in Laboratory Medicine: P-44 Random Amplified polymorphic DNA (RAPD) - A Tool for Gene Mapping. National Conference on Advances in Laboratory Medicine 2015: 163 167

Sambrook J, Russel DW. 2001. Molecular Cloning (A Laboratory Manual). Cold Spring Harbor Laboratory Press, New York.

Saragih GS, Siswadi S. 2019. Antioxidant activity of plant parts extracts from Sterculia quadrifida R.Br. Asian J Pharmaceut Clin Res 12 (7): 143-148.
Siswadi, Grace SS, Heny R. 2013. Potential distributions and utilization of faloak (Sterculia quadrifida R.Br. 1844) on Timor Island, East Nusa Tenggara. Prooceding International Conference Forest and Biodiversity. Balai Penelitian Kehutanan Kupang Press, Kupang. [Indonesian]

Sukhumsirichart W. 2018. Polymorphisms. In: Yamin L (eds.). Genetic diversity and Disease Susceptibility. IntechOpen, Arizona.

Sundari, Arumingtyas EL, Hakim L, Azrianingsih R, Wahyudi D. 2017. Genetic variability of local durian (Durio zibethinus Murr.) in Ternate Island based on RAPD markers. Plant Cell Biotechnol Mol Biol 18 (1): 68-75.

Wahyudi D, Hapsari L, Sundari. 2020. RAPD Analysis for genetic variability detection of mutant soybean (Glycine max (L.) Merr). J Trop Biodiv Biotechnol 5 (1): 68-77.

Wahyudi D, Rifliyah K, Uslan. 2020. Genome evaluation of banana cultivars based on morphological character and Inter-Simple Sequence Repeat (ISSR) molecular marker. Biodiversitas 21 (7): 2982-2990. DOI: 10.13057/biodiv/d210715

Winata A, Triana H, Purwantiningsih, Siswadi. 2019. In vivo immunomodulatory activity of faloak bark extract (Sterculia quadrifida R.Br). Pakistan J Biol Sci 22 (12): 590-596.

Yulita KS, Rahmat HH. 2019. Population genetic structure and diversity of a critically endangered ramin [Gonystylus bancanus Miq. (Kurz), Thymelaeaceae] form Kalimantan and Sumatra based on Sequence Random Amplified Polymorphism. Earth Env Sci 308: 1-9. DOI: 10.1088/1755-1315/308/1/012067. 